\title{
Isotopic composition of dissolved inorganic nitrogen in high mountain lakes: variation with altitude in the Pyrenees
}

\author{
M. Bartrons, L. Camarero, and J. Catalan \\ Centre for Advanced Studies of Blanes (CEAB), CSIC, Accés Cala St. Francesc, 14, Blanes, 17300, Spain \\ Received: 20 November 2009 - Published in Biogeosciences Discuss.: 11 December 2009 \\ Revised: 27 April 2010 - Accepted: 28 April 2010 - Published: 10 May 2010
}

\begin{abstract}
Nitrogen deposition in remote areas has increased, but the effect on ecosystems is still poorly understood. For aquatic systems, knowledge of the main processes driving the observed variation is limited, as is knowledge of how changes in nitrogen supply affect lake biogeochemical and food web processes. Differences in dissolved inorganic nitrogen (DIN) between lakes cannot be understood without considering catchment characteristics. In mountains, catchment features (e.g., thermal conditions, land cover) vary considerably with elevation. The isotopic composition of nitrogen $\left(\delta^{15} \mathrm{~N}\right)$ is increasingly used to study aquatic ecosystem dynamics. Here we explore the variability of $\delta^{15} \mathrm{~N}$ in DIN in high mountain lakes and show that environmental conditions that change with altitude can affect the isotopic ratio.

We measured ammonium and nitrate $\delta^{15} \mathrm{~N}$ values in atmospheric deposition, epilimnetic water, deep chlorophyll maximum water (DCMW) and sediment pore water (SPW) from eight mountain lakes in the Pyrenees, both above and below the treeline. Lakes showed relatively uniform $\delta^{15} \mathrm{~N}^{-\mathrm{NH}_{4}^{+}}$ values in SPW $(2.2 \pm 1.6 \%$ ) , with no variation corresponding to catchment or lake characteristics. We suggest that organic matter diagenesis under similar sediment conditions is responsible for the low variation between the lakes.
\end{abstract}

In the water column, the range of $\delta^{15} \mathrm{~N}$ values was larger for ammonium (-9.4\%o to $7.4 \%$ ) than for nitrate $(-11.4 \%$ o to $-3.4 \%$ ) , as a result of higher variation both between and within lakes (epilimnetic vs. DCM water). For

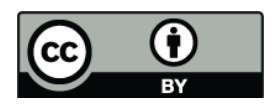

Correspondence to: M. Bartrons (mbartrons@ceab.csic.es) both compounds part of the difference correlated with altitude or catchment features (e.g., scree proportion). Based on concentration, chemical and isotopic tendencies, we suggest that patterns arise from the distinct relative contributions of two types of water flow paths to the lakes: one from snowpack melting, with little soil interaction; and another highly influenced by soil conditions. The snow-type flow path contributes low DIN concentrations depleted in ${ }^{15} \mathrm{~N}$, whereas the soil-type flow path contributes high nitrate concentrations with higher $\delta^{15} \mathrm{~N}$. The proportion of these two types of source correlates with average catchment features when there is extensive snow cover during spring and early summer and probably becomes more dependent on local characteristics around the lake as summer advances. Lake depth and pore water ammonium concentrations, among other features, introduce secondary variation. In the context of nitrogen deposition studies, lakes with higher snow-type influence will probably register changes in $\mathrm{N}$ deposition and pollution sources better, whereas lakes with higher soil-type influence may reflect long-term effects of vegetation and soil dynamics.

\section{Introduction}

The global nitrogen cycle has been modified by human activities during recent centuries with an increase in the amount of reactive nitrogen (i.e., $\mathrm{NH}_{4}^{+}$and $\mathrm{NO}_{3}^{-}$) circulating (Gruber and Galloway, 2008). As part of this change, there has been an increase in nitrogen deposition in remote areas, which is affecting ecosystems in a way that is still poorly understood.

Published by Copernicus Publications on behalf of the European Geosciences Union. 


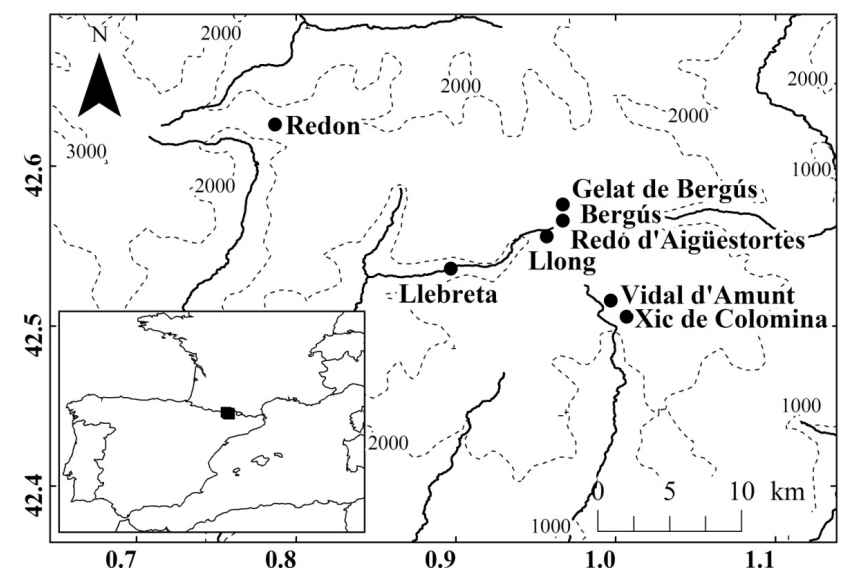

Fig. 1. Map showing the location of the eight lakes in the "Aigüestortes i Estany de Sant Maurici" National Park, Central Pyrenees (Spain).

High mountain lakes are among such ecosystems (Mosello et al., 2002; Kopacek et al., 2005; Catalan et al., 2009b). However, there is still only very limited knowledge of the main processes driving the observed variation and how changes in nitrogen supply affect lake biogeochemical pathways and food web processes.

The isotopic composition of nitrogen $\left(\delta^{15} \mathrm{~N}\right)$ is increasingly used to investigate aquatic ecosystem dynamics. Nitrification (Mariotti et al., 1981), denitrification (Choi et al., 2001), N uptake by osmotrophs (Hogberg, 1997), ammonia volatilisation (Hogberg, 1997), organic matter mineralisation (Lehmann et al., 2002), atmospheric $\mathrm{N}_{2}$ fixation (Shearer and Kohl, 1986), assimilation (Wada and Hattori, 1978; Doi et al., 2004) and diffusion between compartments (e.g., sediment - water; Owens, 1987) can produce changes in isotopic $\mathrm{N}$ composition. Therefore, measurement of the isotopic composition of nitrogen compounds may be helpful for both biogeochemical and food web studies (Fry, 2006). It is still necessary to explore the patterns and range of $\delta^{15} \mathrm{~N}$, and their origins, in systems for which we have little information on $\delta^{15} \mathrm{~N}$ variation, such as mountain lakes.

Atmospheric deposition is the dominant source of $\mathrm{N}$ compounds in most high mountain catchments; it outstrips biological fixation of atmospheric molecular nitrogen (Wookey et al., 2009). Nitrate and ammonium are deposited in similar proportions in European mountains (Camarero and Catalan, 1993, 1996; Rogora et al., 2001; Croisé et al., 2005). However, $\mathrm{NO}_{3}^{-}$is the most common form of $\mathrm{N}$ that enters lakes from catchments (Hood et al., 2003; Kopacek et al., 2005). Ammonium is either retained to a large extent in the catchment, by biological assimilation and sorption in mineral soil horizons, or transformed into $\mathrm{NO}_{3}^{-}$by bacterial nitrification (Campbell et al., 2000). Therefore, differences in dissolved inorganic nitrogen (DIN) in lakes cannot be understood without also considering catchment characteristics. In mountains, catchment characteristics vary considerably with elevation (Korner, 2007). In addition to thermal conditions, the extent and characteristics of soils and vegetation change. In this study, our aims were to explore the variation in $\delta^{15} \mathrm{~N}$ in DIN in high mountain lakes and how changing environmental conditions with increasing altitude can affect the isotopic ratio.

\section{Materials and methods}

\subsection{Study sites}

We sampled eight lakes at altitudes ranging from $1620 \mathrm{~m}$ a.m.s.l. and $2688 \mathrm{ma}$ a.m.s.l. (Table 1) in the Central Pyrenees (NE Spain) (Fig. 1). They are located within an area less than $15 \mathrm{~km}$ in radius, and belong to three different water catchment basins. All the lake basins are on granodioritic bedrock of the Maladeta batholiths; however, those lakes located in large catchments receive some runoff influence from other lithologies. For each lake catchment, the proportion of different land cover types is described in a previous study (Casals-Carrasco et al., 2009). The altitudinal gradient includes a shift in land cover, from a dominance of bare rock and thin, poor soils at high altitudes to extensively vegetated areas and well-developed soils at lower sites (Table 1). For operative purposes, we amalgamated the land cover types into four categories (thick soil, thin soil, scree and rocks), which are representative of the largest contrasts in biogeochemical characteristics. The treeline is on average around $2150 \mathrm{~m}$ a.s.l. in this area.

Average water residence time in these lakes is relatively short; it varies from less than one year for most of the lakes to several years for the deepest ones. Depth increases with lake area due to the common geomorphological origin of the lakes (Catalan et al., 2009a) and lake volume is proportional to lake area. The ratio between catchment area and lake area is a good indicator of water retention time (Table 1). Small lakes low down the valleys (e.g., Llebreta) have shorter retention times; whereas large cirque lakes (e.g., Redon) have the highest.

The general physical and chemical characteristics of the lakes are relatively similar (Table 1), with the exception of depth. The lakes are dimictic, covered by ice for 5 to 8 months a year, oligotrophic, and have low ion content and acid-buffering capacity. We used conductivity, acid-neutralising capacity (ANC), $\mathrm{pH}$, sulphate and chloride to characterise the main chemical differences between the lakes. We used total phosphorus, dissolved inorganic carbon (DIC), dissolved organic carbon (DOC), and dissolved reactive silica (DRSi) to characterise the tropho-dynamics of the lakes. During summer stratification, the photic zone is deeper than the thermocline in these lakes. Light penetration is high and the Secchi disk may be as deep as $20 \mathrm{~m}$. Therefore, irradiance at the bottom is sufficient for algal growth in 
Table 1. Physical and epilimnetic chemical characteristics of the lakes.

\begin{tabular}{|c|c|c|c|c|c|c|c|c|}
\hline & $\begin{array}{r}\text { Llebreta } \\
\text { (1) }\end{array}$ & $\begin{array}{l}\text { Llong } \\
\text { (2) }\end{array}$ & $\begin{array}{r}\text { Redó } \\
\text { d'Aigüestortes } \\
\text { (3) }\end{array}$ & $\begin{array}{r}\text { Redon } \\
\text { (4) }\end{array}$ & $\begin{array}{r}\text { Xic de } \\
\text { Colomina } \\
(5)\end{array}$ & $\begin{array}{r}\text { Bergús } \\
\text { (6) }\end{array}$ & $\begin{array}{r}\text { Gelat de } \\
\text { Bergús } \\
(7)\end{array}$ & $\begin{array}{r}\text { Vidal } \\
\text { d'Amunt } \\
\text { (8) }\end{array}$ \\
\hline Latitude $-\mathrm{N}$ & 42.55 & 42.57 & 42.58 & 42.64 & 42.52 & 42.59 & 42.59 & 42.53 \\
\hline Longitude - E & 0.89 & 0.95 & 0.96 & 0.78 & 1.00 & 0.96 & 0.96 & 0.99 \\
\hline Altitude (m a.s.1.) & 1620 & 2000 & 2150 & 2240 & 2425 & 2449 & 2500 & 2688 \\
\hline Catchment area (ha) & 5438 & 1111 & 322 & 153 & 35 & 101 & 24 & 17 \\
\hline \multicolumn{9}{|l|}{ Catchment land cover $(\%)$} \\
\hline Rock (Outcrops, scarps) & 18.9 & 26.7 & 23.1 & 18.7 & 20.2 & 31.6 & 51.7 & 51.2 \\
\hline Scree & 30.0 & 30.3 & 57.4 & 36.5 & 49.5 & 64.1 & 39.6 & 46.2 \\
\hline Thin soil (alpine meadows) & 9.5 & 13.1 & 8.5 & 36.2 & 15.9 & 2.5 & 4.5 & 1.4 \\
\hline Thick soil (shrubs, forest) & 41.7 & 29.9 & 11.0 & 8.6 & 14.4 & 1.8 & 4.1 & 1.2 \\
\hline Lake area (ha) & 8.0 & 7.1 & 6.0 & 24.1 & 1.8 & 6.5 & 1.4 & 2.3 \\
\hline Maximum depth (m) & 10.5 & 12 & 10 & 73 & 11 & 50 & 7.5 & 18 \\
\hline Conductivity $\left(\mu \mathrm{S} \mathrm{cm}^{-1}\right)$ & 42 & 29 & 12 & 11 & 25 & 13 & 8 & 24 \\
\hline Sulphate $\left(\mu \mathrm{eq} \mathrm{L}^{-1}\right)$ & 50 & 33 & 16 & 18 & 21 & 14 & 14 & 17 \\
\hline Chloride $\left(\mu \mathrm{eq} \mathrm{L}{ }^{-1}\right)$ & 7 & 5 & 4 & 6 & 5 & 10 & 5 & 7 \\
\hline Acid-neutralising capacity $\left(\mu \mathrm{eq} \mathrm{L}^{-1}\right)$ & 327 & 235 & 71 & 59 & 209 & 73 & 42 & 201 \\
\hline $\mathrm{pH}$ & 7.4 & 7.5 & 7.0 & 7.0 & 7.5 & 7.0 & 6.8 & 7.5 \\
\hline Dissolved inorganic carbon $\left(\mathrm{mg} \mathrm{L}^{-1}\right)$ & 3.9 & 2.7 & 0.9 & 0.7 & 2.5 & 0.9 & 0.6 & 2.4 \\
\hline Dissolved organic carbon $\left(\mathrm{mg} \mathrm{L}^{-1}\right)$ & 1.4 & 1.7 & 1.0 & 1.3 & 2.1 & 1.0 & 1.1 & 2.2 \\
\hline Sediment organic matter $(\%)$ & 26.4 & 23.3 & 22.9 & 22.1 & 26.0 & 18.3 & 16.3 & 24.5 \\
\hline Photic index ${ }^{1}(\%)$ & 100 & 100 & 100 & 27 & 100 & 40 & 100 & 39 \\
\hline Total phosphorus $\left(\mu \mathrm{g} \mathrm{L}^{-1}\right)$ & 7.8 & 9.5 & 7.5 & 5.2 & 6.3 & 4.3 & 5.4 & 7.9 \\
\hline Dissolved reactive silica $\left(\mu \mathrm{mol} \mathrm{L}{ }^{-1}\right)$ & 48 & 25 & 31 & 8 & 21 & 30 & 18 & 16 \\
\hline
\end{tabular}

${ }^{1}$ Photic index $=$ Secchi disk depth/Lake depth $\times 100$.

shallow lakes ( $<\sim 15 \mathrm{~m}$ deep; Buchaca and Catalan, 2008). In order to take this into account, we used a photic index consisting of the ratio between the Secchi disk depth and lake depth, expressed as a percentage (Catalan et al., 2009b).

\subsection{Sampling}

In alpine lakes in temperate zones, after the snow and ice cover melts, the water column mixes and $\mathrm{NH}_{4}^{+}$and $\mathrm{NO}_{3}^{-}$concentrations homogenise throughout the water column (Catalan, 1992; Catalan et al., 2002). As soon as lake water reaches $4{ }^{\circ} \mathrm{C}$, the water column stratifies, phytoplankton blooms, and the physical, chemical and biological characteristics of the epilimnetic and hypolimnetic layers start to diverge. Deep chlorophyll maximum (DCM) develops at about 1.5 times the Secchi disk depth, or just a few centimetres above the bottom in shallow lakes (Catalan et al., 2002). In accordance with this seasonal pattern, we sampled the lakes in the middle of the stratification period to evaluate differentiation within the water column. To examine $\delta^{15} \mathrm{~N}$ variation in DIN, we considered three lake compartments, namely: epilimnetic water (EW); DCM water (DCMW) and upper sediment pore water (SPW). Typically, DIN concentrations are established during the thawing period, when about half of the year's precipitation enters the lake as snowmelt in a few weeks (Catalan, 1992). Catchment characteristics may have a large influence at this point; conditioning the water flow path to the lakes. After stratification, EW is more likely to be influenced by inflow water than DCMW and SPW; whereas the latter two may continue to interact mutually. Inflow water is richer in $\mathrm{NO}_{3}^{-}$than in $\mathrm{NH}_{4}^{+}$, and DIN is higher than dissolved organic nitrogen (DON). This is a general feature in alpine catchments (Hood et al., 2003; Kopacek et al., 2005). We have data from two lakes (L. Camarero, personal communication, 2009) that confirm this general feature during the period of our study (Table 2).

The lakes were sampled during the first week of August 2006. EW, DCMW and SPW from each lake were analysed for $\mathrm{NO}_{3}^{-}, \mathrm{NH}_{4}^{+}, \delta^{15} \mathrm{~N}-\mathrm{NO}_{3}^{-}$and $\delta^{15} \mathrm{~N}-\mathrm{NH}_{4}^{+}$content, as well as other physical and chemical properties. EW was sampled at $1 \mathrm{~m}$ depth, DCMW at 1.5 times the Secchi disk depth or alternatively, $1 \mathrm{~m}$ above the bottom when the Secchi disk was still visible at the bottom of the lake. These two water column samples were collected by means of a Ruttner bottle. Samples for $\delta^{15} \mathrm{~N}-\mathrm{NO}_{3}^{-}$analysis were fieldfiltered (pre-ashed Whatman GF/F, $0.7 \mu \mathrm{m}$ pore size) into clean polypropylene hermetic bottles and stored at $-20^{\circ} \mathrm{C}$ until analysis, following Spoelstra et al. (2004). With this 
Table 2. Average dissolved nitrogen concentration in inlets (June 2004 to April 2006) and annual loading (2006) into two of the lakes studied.

\begin{tabular}{lccc}
\hline & $\mathrm{NO}_{3}^{-}$ & $\mathrm{NH}_{4}^{+}$ & $\mathrm{DON}$ \\
\hline Concentration $\left(\mu \mathrm{mol} \mathrm{L}^{-1}\right)$ & & & \\
Llebreta inlet & $18 \pm 2$ & $0.2 \pm 0.2$ & $4 \pm 4$ \\
Llong inlet a & $15 \pm 4$ & $0.2 \pm 0.2$ & $5 \pm 4$ \\
Llong inlet b & $12 \pm 3$ & $0.3 \pm 0.2$ & $5 \pm 4$ \\
Input fluxes $\left(\mathrm{kmol} \mathrm{y}^{-1}\right)$ & & & \\
Llebreta inflow & 529 & 2.7 & \\
Llebreta deposition & 3 & 2.5 & \\
Llong inflows & 140 & 1.8 & \\
Llong deposition & 3 & 2.4 & \\
\hline
\end{tabular}

method, Spoelstra et al. (2004) detected no $\mathrm{NO}_{3}^{-}$production or assimilation in the samples over a two-week incubation period and found that atmospheric $\mathrm{NO}_{3}^{-}$isotopic ratios were preserved.

SPW was sampled using a gravity core. Immediately, the first five centimetres were extruded and stored in a hermetic polypropylene bag without air. This bag was transported cold to the lab where it was frozen. After defrosting, SPW was obtained by high-pressure filtration with Whatman GF/F, 0.7 $\mu \mathrm{m}$ pore size.

To have an initial reference of $\delta^{15} \mathrm{~N}$, bulk deposition was sampled fortnightly from 1 June to 25 August 2006. Samples were collected at $2240 \mathrm{~m}$ a.s.l. on the shore of lake Redon; this elevation corresponds to the middle of the lake altitude distribution. Due to the previously observed lack of significant differences in the chemistry of bulk precipitation in this area within the lake altitude range (Camarero and Catalan, 1996), deposition at this point was considered representative. The analytical procedures applied to bulk deposition samples were the same as those used for the water column samples.

\subsection{Chemical analysis}

Ammonium was determined following Solórzano (1969). Nitrate, chloride and sulphate were determined using a Waters Quanta 4000 Capillary Electrophoresis system. pH was measured with an Orion Research model 720A pHmeter, with a low ionic strength filling solution in the $\mathrm{pH}$ electrode $(\mathrm{KCl} 1 \mathrm{M})$. Sediment organic matter was estimated as weight loss on ignition (LOI) at $550^{\circ} \mathrm{C}$ (Heiri et al., 2001). ANC was determined by Gran titration. Conductivity was determined with an Instran-10 conductimeter. DIC and DOC were determined by IR absorption using a Shimadzu TOC-5000 analyzer. Total phosphorus was determined according to the Malachite green method, with previous acid persulphate digestion (Camarero, 1994). DRSi was determined by the blue silicon-molybdenum method (Grasshoff et al., 1983).
Stable isotopic ratios of $\mathrm{NH}_{4}^{+}$and $\mathrm{NO}_{3}^{-}$were determined by the alkaline headspace diffusion methods of Holmes et al. (1998) and Sigman et al. (1997), respectively. For the $\delta^{15} \mathrm{~N}$ of $\mathrm{NH}_{4}^{+}$, magnesium oxide $(\mathrm{MgO})$ was added to increase the $\mathrm{pH}$ and to convert $\mathrm{NH}_{4}^{+}$to $\mathrm{NH}_{3}$. A filter pack consisting of an acidified ( $\mathrm{KHSO}_{4} 2.5 \mathrm{M}$ ) glass fibre filter sandwiched between two Teflon filters was placed in each sample bottle in the field. Back in the lab, the samples were incubated on a shaker table at $40^{\circ} \mathrm{C}$ for 14 days, to promote diffusion of $\mathrm{NH}_{3}$ towards the filter pack. To determine the $\delta^{15} \mathrm{~N}$ of $\mathrm{NO}_{3}^{-}$, the samples were initially boiled, with $\mathrm{MgO}$ added, and vaporised to $100 \mathrm{~mL}$ to concentrate and drive off $\mathrm{NH}_{4}^{+}$as $\mathrm{NH}_{3}$. Thereafter, Devarda's alloy was added to the samples, which were placed in an oven at $60^{\circ} \mathrm{C}$ for $48 \mathrm{~h}$ to reduce $\mathrm{NO}_{3}^{-}$to $\mathrm{NH}_{4}^{+}$. The rest of the $\delta^{15} \mathrm{~N}^{-\mathrm{NO}_{3}^{-}}$procedure was the same as for $\delta^{15} \mathrm{~N}^{-\mathrm{NH}_{4}^{+}}$. Filter packs from these analyses were analysed for the nitrogen isotopic ratio on a Europa Integra mass spectrometer (Sercon) at the University of California Davis Stable Isotope Facility. During analysis, samples were interspersed with several replicates of at least two different laboratory standards. These laboratory standards, which were selected to be compositionally similar to the samples being analysed, had previously been calibrated against NIST Standard Reference Materials (IAEA-N1, IAEA-N2, IAEA-N3 and IAEA-CH7) (Gonfiantini, 1978). The preliminary isotope ratio was measured relative to reference gases analysed with each sample. These preliminary values were finalised by adjusting the values for the entire batch based on the known values of the laboratory standards included. The precision of replicate analyses of standards was $0.2 \%$. Corrections to isotope values were calculated following Holmes et al. (1998) and Sigman et al. (1997). Standards were analysed concurrently, with every set of samples analysed for nitrate and ammonium $\delta^{15} \mathrm{~N}$. They were prepared by adding an $\mathrm{NH}_{4}^{+}$stock solution of known isotopic composition to the same bottles to achieve an $\mathrm{NH}_{4}^{+}$concentration similar to that expected. We used deviations between the known concentration and isotopic composition of the standards and the values obtained after the procedure to correct the sample results. $\delta^{15} \mathrm{~N}^{-N^{-}}$, values were also corrected for any $\mathrm{N}$ added due to Devarda's alloy contamination (Devarda's blanks), as described in Sigman et al. (1997). Deviations due to the different bottle volumes used during the analysis were also corrected for following Holmes et al. (1998). $\mathrm{NO}_{3}^{-}$concentrations in SPW were very low; as a result, $\mathrm{SPW} \mathrm{NO}_{3}^{-}$isotopic composition could not be determined as it would have required about $4 \mathrm{~L}$ of pore water. 
Table 3. Descriptive statistics of concentration and isotopic composition of ammonium and nitrate in the lake compartments and deposition.

\begin{tabular}{lrrrr}
\hline & Mean & $\begin{array}{r}\text { Standard } \\
\text { deviation }\end{array}$ & Minimum & Maximum \\
\hline $\mathrm{NH}_{4}^{+}\left(\mu \mathrm{mol} \mathrm{L}^{-1}\right)$ & & & & \\
$\mathrm{EW}$ & 0.8 & 0.4 & 0.4 & 1.6 \\
$\mathrm{DCMW}$ & 0.9 & 0.4 & 0.4 & 1.6 \\
$\mathrm{SPW}$ & 98 & 72 & 9.6 & 258 \\
Deposition & $47^{*}$ & $30^{*}$ & 12 & 102 \\
\hline $\mathrm{NO}_{3}^{-}\left(\mu \mathrm{mol} \mathrm{L}^{-1}\right)$ & & & & \\
$\mathrm{EW}_{\mathrm{DCMW}}$ & 8.2 & 5.0 & 0.0 & 14.4 \\
$\mathrm{SPW}$ & 8.3 & 5.2 & 0.0 & 16.2 \\
Deposition & 1.5 & 1.7 & 0.0 & 3.6 \\
\hline$\delta^{15} \mathrm{~N}-\mathrm{NH}_{4}^{+}(\% \circ)$ & $40^{*}$ & $17^{*}$ & 14 & 70 \\
EW & -2.68 & 4.34 & -8.47 & 4.06 \\
DCMW & -0.27 & 6.33 & -9.42 & 7.39 \\
SPW & 2.18 & 1.55 & 0.36 & 5.11 \\
Deposition & $-2.50^{*}$ & $3.70^{*}$ & -8.51 & 2.02 \\
\hline$\delta^{15} \mathrm{~N}-\mathrm{NO}_{3}^{-}(\% \circ)$ & & & & \\
EW & -6.28 & 1.46 & -8.57 & -3.46 \\
DCMW & -6.70 & 2.52 & -11.40 & -4.16 \\
SPW & - & - & - & - \\
Deposition & $-4.40^{*}$ & $4.70^{*}$ & -8.49 & 4.99 \\
\hline
\end{tabular}

* Weighted by precipitation volume.

\section{Results}

\subsection{General patterns}

Simple statistics indicated contrasting patterns across lake compartments both of concentration and isotopic composition of $\mathrm{NO}_{3}^{-}$and $\mathrm{NH}_{4}^{+}$(Table 3 ). $\mathrm{SPW} \mathrm{NH}_{4}^{+}$concentrations were remarkably high compared to water column values (i.e., EW and DCMW); about two orders of magnitude higher. SPW $\mathrm{NO}_{3}^{-}$concentration was lower than that in the water column, below $1 \mu \mathrm{mol} \mathrm{L}{ }^{-1}$ in four lakes. Such low concentrations made determination of $\delta^{15} \mathrm{~N}-\mathrm{NO}_{3}^{-}$in pore water unfeasible using our method. SPW $\delta^{15} \mathrm{~N}-\mathrm{NH}_{4}^{+}$values were always positive, generally higher than in the water column, and showed less variability across lakes than EW and, particularly, DCMW values (Table 3).

In contrast with sediments, $\mathrm{NH}_{4}^{+}$concentration in the water column was low compared to $\mathrm{NO}_{3}^{-}$(Table 3). There were no significant differences in $\mathrm{NH}_{4}^{+}$concentrations between EW and DCMW values (paired $t=0.6, \mathrm{df}=14, p$ value $<0.5$ ) (Fig. 2). Likewise for $\mathrm{NO}_{3}^{-}$concentrations there were no differences between EW and DCMW (paired $t=0.6$, $\mathrm{df}=7, p$-value $=0.6$ ), despite the range of $\mathrm{NO}_{3}^{-}$concentrations across the lakes being larger than for $\mathrm{NH}_{4}^{+}$(Fig. 2). In contrast, the range of $\delta^{15} \mathrm{~N}-\mathrm{NH}_{4}^{+}$values was much larger
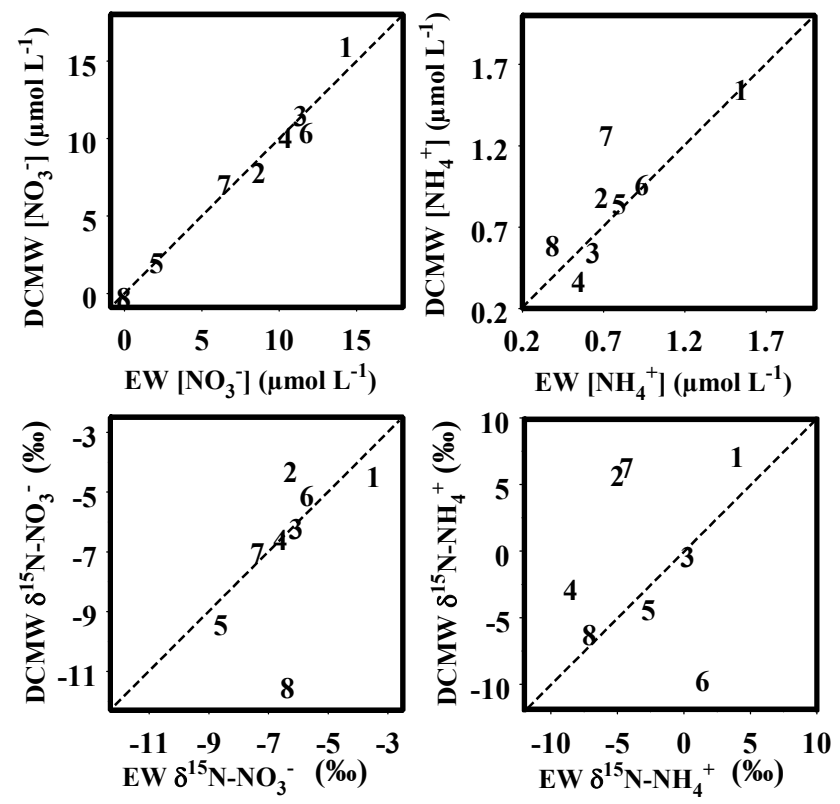

Fig. 2. Relationships between epilimnetic water (EW) and deep chlorophyll maximum water (DCMW) in terms of nitrate and ammonium concentrations and $\delta^{15} \mathrm{~N}$, from the eight Pyrenean lakes studied (lakes numbered according to Table 1).

than for $\delta^{15} \mathrm{~N}_{-} \mathrm{NO}_{3}^{-}$; the former exceeding the whole range found in deposition and pore water (Table 3, Fig. 2). EW and DCMW $\delta{ }^{15} \mathrm{~N}-\mathrm{NH}_{4}^{+}$were not significantly different (paired $t=-0.9, \mathrm{df}=7, p$-value $=0.4$ ), although dispersion increased in DCMW compared to EW (Table 3). Water column $\delta^{15} \mathrm{~N}^{-N^{-}} \mathrm{O}_{3}^{-}$values were generally lower than in deposition, again without significant differences between EW and DCMW (paired $t=0.6, \mathrm{df}=7, p$-value=0.6). In summary, water column DIN is characterised by higher concentrations of $\mathrm{NO}_{3}^{-}$than $\mathrm{NH}_{4}^{+}$, large variability among lakes, and statistically non-significant isotopic composition differences between EW and DCMW.

The isotopic composition and concentration of $\mathrm{NH}_{4}^{+}$and $\mathrm{NO}_{3}^{-}$were not independent in all cases (Table 4). The highest dependency was shown by DCMW and EW $\delta^{15} \mathrm{~N}$ $\mathrm{NO}_{3}^{-}$, which both correlated with water column $\mathrm{NO}_{3}^{-}$concentrations, in addition, DCMW $\delta^{15} \mathrm{~N}-\mathrm{NO}_{3}^{-}$correlated with SPW NO${ }_{3}^{-}$and $\mathrm{NH}_{4}^{+}$concentrations. Epilimnetic $\delta^{15} \mathrm{~N}-\mathrm{NH}_{4}^{+}$ was also related to concentration in that compartment. However, neither DCMW nor SPW $\delta^{15} \mathrm{~N}-\mathrm{NH}_{4}^{+}$correlated with concentrations (Table 4).

\subsection{Relationships between isotopic composition and environmental features}

Isotopic composition correlated with a number of environmental variables (Table 4), with the exception of SPW $\delta^{15} \mathrm{~N}$ $\mathrm{NH}_{4}^{+}$, which did not show any significant correlations. The environmental variables that correlate with isotopic 


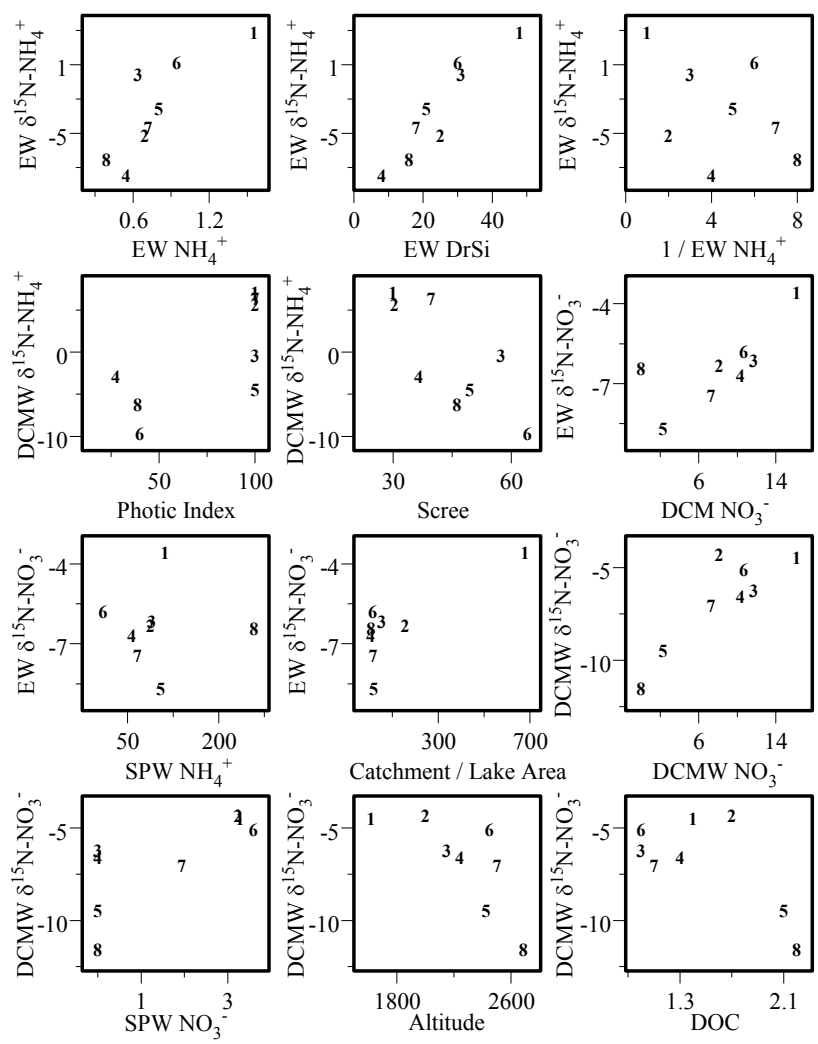

Fig. 3. Relationships between $\delta^{15} \mathrm{~N}-\mathrm{NO}_{3}^{-}$and $\delta^{15} \mathrm{~N}-\mathrm{NH}_{4}^{+}$, from epilimnetic water (EW) and deep chlorophyll maximum water (DCMW), and different lake variables. The eight Pyrenean lakes studied are numbered according to Table $1 . \delta^{15} \mathrm{~N}$ values are expressed in \%o, concentration of ammonium $\left(\mathrm{NH}_{4}^{+}\right)$, nitrate $\left(\mathrm{NO}_{3}^{-}\right)$ and dissolved reactive silica (DRSi) in $\mu \mathrm{mol} \mathrm{L}^{-1}$, photic index and scree in $\%$, altitude in $\mathrm{m}$ a.s.l. and dissolved organic carbon (DOC) in $\mathrm{mg} \mathrm{L}^{-1}$.

composition were different for $\mathrm{NH}_{4}^{+}$and $\mathrm{NO}_{3}^{-}$and also differed between EW and DCMW (Table 4). Due to the tendencies inherent to the altitudinal gradient, some of the relationships observed (Tabla 4) could be redundant. In order to clarify the strongest relationships, we performed stepwise regressions (Venables and Ripley, 1994) to obtain appropriate models that avoid redundancy in describing the relationships (Table 5). Due to the small number of observations, we performed three types of stepwise regression: one based on concentrations as explanatory variables; another based on environmental factors and a final one mixing the variables selected in the two previous models.

EW $\delta^{15} \mathrm{~N}-\mathrm{NH}_{4}^{+}$was mainly related to DRSi (Table 5): the higher the DRSi, the higher $\delta^{15} \mathrm{~N}$ (Fig. 3). DRSi overrides $\mathrm{NH}_{4}^{+}$concentration, which was also correlated to EW $\delta^{15} \mathrm{~N}-\mathrm{NH}_{4}^{+}$. DCMW $\delta^{15} \mathrm{~N}-\mathrm{NH}_{4}^{+}$was related to scree proportion in the catchment and to photic index. These two variables showed complementary explicative capacity (Fig. 3). DCMW $\delta{ }^{15} \mathrm{~N}-\mathrm{NH}_{4}^{+}$decreased with increasing scree
Table 4. Correlation ( $r$ values) between isotopic composition of nitrate and ammonium in the different lake compartments and ammonium and nitrate concentrations and environmental variables. Only variables with some significant relationship are listed, all environmental variables in Table 2 were tested.

\begin{tabular}{lrrrrr}
\hline & \multicolumn{3}{c}{$\delta^{15} \mathrm{~N}-N H_{4}^{+}$} & \multicolumn{2}{c}{$\delta^{15} \mathrm{~N}^{-N^{-}}$} \\
& $\mathrm{EW}$ & $\mathrm{DCMW}$ & $\mathrm{SPW}$ & $\mathrm{EW}$ & $\mathrm{DCMW}$ \\
\hline $\mathrm{EW} \mathrm{NH}_{4}^{+}$ & $0.83^{\mathrm{b}}$ & 0.39 & -0.23 & 0.66 & 0.57 \\
$\mathrm{SPW} \mathrm{NH}_{4}^{+}$ & -0.31 & -0.07 & 0.27 & 0.01 & $-0.73^{\mathrm{a}}$ \\
$\mathrm{EW} \mathrm{NO}_{3}^{-}$ & 0.59 & 0.32 & -0.18 & $0.71^{\mathrm{a}}$ & $0.90^{\mathrm{c}}$ \\
$\mathrm{DCMW} \mathrm{NO}_{3}^{-}$ & 0.63 & 0.42 & -0.19 & $0.74^{\mathrm{a}}$ & $0.87^{\mathrm{b}}$ \\
$\mathrm{SPW} \mathrm{NO}_{3}^{-}$ & 0.52 & 0.35 & -0.50 & 0.56 & $0.74^{*}$ \\
Altitude & -0.53 & -0.65 & 0.11 & $-0.70^{\mathrm{a}}$ & $-0.74^{\mathrm{a}}$ \\
Catchment/lake area & 0.62 & 0.59 & -0.21 & $0.80^{\mathrm{b}}$ & 0.48 \\
Scree & 0.27 & $-0.77^{\mathrm{b}}$ & 0.60 & -0.25 & -0.23 \\
Thick soil & 0.44 & $0.68^{\mathrm{a}}$ & -0.13 & 0.56 & 0.56 \\
Sulphate & 0.45 & 0.61 & -0.23 & $0.67^{\mathrm{a}}$ & 0.47 \\
DOC & -0.41 & -0.17 & 0.16 & -0.33 & $-0.68^{\mathrm{a}}$ \\
Photic index & 0.43 & $0.71^{\mathrm{a}}$ & 0.20 & -0.03 & 0.28 \\
DRSi & $0.93^{\mathrm{c}}$ & 0.35 & 0.16 & $0.74^{\mathrm{a}}$ & 0.55 \\
\hline
\end{tabular}

${ }^{\mathrm{a}} p<0.05 ;{ }^{\mathrm{b}} p<0.01 ;{ }^{\mathrm{c}} p<0.001$

proportion in the catchment, and this decline was accentuated in lakes where Secchi disk visibility did not reach the lake bottom (photic index $<100 \%$ ).

The ratio between catchment and lake areas was the environmental factor that showed the best relationship with EW $\delta^{15} \mathrm{~N}_{-} \mathrm{NO}_{3}^{-}$. This was mainly due to the influence of Llebreta; a lake with exceptionally high EW $\delta^{15} \mathrm{~N}-\mathrm{NO}_{3}^{-}$ and catchment/lake area ratio. The relationship may therefore be spurious; excluding Llebreta from the analysis results in a non-significant relationship $\left(r^{2}=0.06 ; p<0.60\right)$. In the mixed model, the concentration variables override the explicative capacity of catchment/lake area ratio (Table 5). DCMW $\mathrm{NO}_{3}^{-}$was highly correlated to $\mathrm{EW} \delta^{15} \mathrm{~N}^{-\mathrm{NO}_{3}^{-}}$and residuals were partially accounted for by $\mathrm{SPW} \mathrm{NH}_{4}^{+}$(Fig. 3).

Altitude on its own shows up in explaining DCMW $\delta^{15} \mathrm{~N}$ $\mathrm{NO}_{3}^{-}$(Fig. 3) and was complementary to DOC (Table 5). In this case, the mixed model included the two environmental variables and one concentration $\left(\mathrm{SPW} \mathrm{NO}_{3}^{-}\right)$.

\section{Discussion}

The variation in isotopic composition of dissolved compounds in a given compartment results from the mixing of different sources of DIN or fractionation due to ongoing in situ processes. Fractionation generally occurs if there is a large pool of substrate and the amount actually used in the process is small compared to the pool size (Hoch et al., 1992; York et al., 2007). The negative values of $\delta^{15} \mathrm{~N}$ in deposition show the pollutant origin of at least part of the nitrogen (Moore, 1977; Freyer, 1991; Hastings et al., 2003). $\delta^{15} \mathrm{~N}-\mathrm{NO}_{3}^{-}$values in the water column were always below 
Table 5. Regression models relating isotopic composition to explanatory variables. Models based on dissolved inorganic nitrogen concentration, environmental variables and mixed models are compared.

\begin{tabular}{|c|c|c|c|c|c|c|c|c|c|}
\hline Response variable model & DIN concentration model & $r^{2}$ & $p$-value & Environment model & $r^{2}$ & $p$-value & Mixed model & $r^{2}$ & $p$-value \\
\hline $\mathrm{EW} \delta^{15} \mathrm{~N}-\mathrm{NH}_{4}^{+}$ & $\mathrm{EW} \mathrm{NH}_{4}^{+}$ & 0.68 & 00 & DRSi & 0.87 & 0.001 & DRSi & 0.87 & 0.001 \\
\hline DCMW $\delta^{15} \mathrm{~N}^{4} \mathrm{NH}_{4}^{+}$ & $-\quad 4$ & & & Scree + Photic index & 0.86 & 0.006 & Scree + Photic index & 0.86 & 0.006 \\
\hline $\mathrm{SPW} \delta^{15} \mathrm{~N}-\mathrm{NH}_{4}^{+}$ & - & - & - & - & - & - & - & - & - \\
\hline $\mathrm{EW} \delta^{15} \mathrm{~N}-\mathrm{NO}_{3}{ }^{4}$ & $\mathrm{DCMW} \mathrm{NO}_{3}^{-}+\mathrm{SPW} \mathrm{NH}_{4}^{+}$ & 0.84 & 0.010 & Catchment/lake ratio & 0.64 & 0.018 & $\mathrm{DCMW} \mathrm{NO}_{3}^{-}+\mathrm{SPW} \mathrm{NH}_{4}^{+}$ & 0.84 & 0.010 \\
\hline DCMW $\delta^{15} \mathrm{~N}-\mathrm{NO}_{3}$ & $\mathrm{DCMW} \mathrm{NO}_{3}^{-}+\mathrm{SPW} \mathrm{NO}_{3}^{-}$ & 0.87 & 0.006 & Altitude + DOC & 0.81 & 0.015 & Altitude $+\mathrm{DOC}+\mathrm{SPW} \mathrm{NO}_{3}^{-}$ & 0.96 & 0.012 \\
\hline
\end{tabular}

the atmospheric ratios in our study, which indicates the influence of additional fractionation. Catchment nitrification is the most likely candidate. Several arguments support this view. $\mathrm{NH}_{4}^{+}$is as abundant as $\mathrm{NO}_{3}^{-}$in deposition and they show similar $\delta^{15} \mathrm{~N}$. However, inflow water entering the lakes is extremely poor in $\mathrm{NH}_{4}^{+}$(Table 2), as in many other mountain ranges (Campbell et al., 2000). Therefore, $\mathrm{NH}_{4}^{+}$is either assimilated by plants and microorganisms, or is nitrified to $\mathrm{NO}_{3}^{-}$. Both processes occur (Campbell et al., 2000). Since $\mathrm{NH}_{4}^{+}$concentration in deposition is high, we can expect fractionation; increasing $\delta^{15} \mathrm{~N}-\mathrm{NH}_{4}^{+}$and decreasing $\delta^{15} \mathrm{~N}-\mathrm{NO}_{3}^{-}$ values. Nitrification has a considerable capacity for fractionation (10-40\%o; Delwiche and Steyn, 1970, and Mariotti et al., 1981).

\subsection{Isotopic composition of ammonium in sediment pore water}

The ammonium isotopic composition of SPW $\left(\delta^{15} \mathrm{~N}-\mathrm{NH}_{4}^{+}\right)$ showed three distinctive features: values were approximately $2 \%$ to $5 \%$ o higher than the corresponding water column values (Table 3); differences in values between lakes were much lower than for values in the water column, particularly compared to DCMW $\delta^{15} \mathrm{~N}-\mathrm{NH}_{4}^{+}$(Table 3 ); and variation in isotopic composition did not correlate with any of the catchment or lake environmental factors considered, nor with $\mathrm{NH}_{4}^{+}$concentrations in SPW.

The relatively low variation in SPW $\delta^{15} \mathrm{~N}-\mathrm{NH}_{4}^{+}$and the lack of correlation with other variables indicates that SPW $\delta^{15} \mathrm{~N}-\mathrm{NH}_{4}^{+}$values probably result from in situ processes. The difference from water column values indicates there is one or more fractionation process, which ultimately enriches sediment ammonium in ${ }^{15} \mathrm{~N}$. These processes will occur independently of altitudinal constraints. This is not surprising since sediment conditions are similar across all the lakes studied: organic matter content is around $20 \%$ and temperature is approximately $4{ }^{\circ} \mathrm{C}$ for most of the year. Because of the large pool of $\mathrm{NH}_{4}^{+}$in pore water (concentrations are orders of magnitude higher than in the water column) fractionation may occur via processes that only use a portion of the whole $\mathrm{NH}_{4}^{+}$pool. There are at least three candidate processes: organic matter diagenesis, nitrification and up-take by periphyton at the sediment/water interface. The three processes fractionate in the same direction; they all result in ${ }^{15} \mathrm{~N}$ enrichment. However, organic matter diagenesis is probably the process which contributes most. Our results are in accordance with Lehmann et al. (2002); organic matter diagenesis would produce enrichment because during mineralisation, lighter $\mathrm{N}$ is first released to the SPW $\mathrm{NH}_{4}^{+}$ pool and taken up, with further fractionation, by microorganisms whose growth is based on further organic matter decomposition. This recursive process results in a progressive enrichment of the SPW $\mathrm{NH}_{4}^{+}$pool until it reaches a certain steady-state that depends on: the input fluxes of organic matter, and the output fluxes by $\mathrm{NH}_{4}^{+}$diffusion and organic matter burial (Lehmann et al., 2002). Nitrification has a considerable capacity for fractionation (10-40\%o; Mariotti et al., 1981); however, it requires oxygenated conditions, which are unlikely except in the uppermost sediment. The lack of correlation between SPW $\delta^{15} \mathrm{~N}_{-} \mathrm{NH}_{4}^{+}$and SPW NO $\mathrm{NO}_{3}^{-}$concentration, and the poor $\delta^{15} \mathrm{~N}-\mathrm{NH}_{4}^{+}$enrichment in relation to water column $\delta^{15} \mathrm{~N}-\mathrm{NH}_{4}^{+}$values suggest that the effects of nitrification in the uppermost sediment are modest. Finally, uptake by periphyton could also contribute. In contrast to lakes with a higher trophic status, these oligotrophic alpine lakes are clear enough to sustain the growth of periphyton on top of the sediment. Ammonium from pore water could be a major source of nitrogen for them. The three lakes with lower photic indexes $(<100 \%)$ showed SPW $\delta{ }^{15} \mathrm{~N}-\mathrm{NH}_{4}^{+}$ values around the mean (approximately 2\%o); lakes with a photic index of $100 \%$ covered the whole range of SPW $\delta^{15} \mathrm{~N}$ $\mathrm{NH}_{4}^{+}(0.4 \%$ o to $5 \%$ ) ; perhaps periphyton activity played an important role in those lakes with values in the upper range.

\subsection{Isotopic composition of DIN in the water column}

The water column system is more open than the sediment system, particularly in these lakes with low water residence times. Seasonality is quite marked. Two aspects are important for interpreting the patterns and relationships observed. First, spring overturn implies a reset and homogenisation of the water column DIN. The large water inflow, due to snowpack thawing, and enhanced water column interaction with sediments, because of mixing, imply high DIN supply to the whole water column in a homogenised way. With the onset of stratification, epilimnetic and hypolimnetic DIN may 
start to differentiate. In addition to water column processes, epilimnetic waters are still open to further inflow influence and depending on lake morphology, the hypolimnion may interact with SPW. During spring overturn, the DIN features will be more or less preserved depending on the intensity of the processes during stratification. In eutrophic lakes, later biological activity will probably erase any initial spring pattern; however, in these very oligotrophic lakes the signature may remain. The second relevant aspect is snowfall. Broadly half of the total precipitation in this area is in the form of snow during winter and early spring (Camarero and Catalan, 1996). During the thaw a large amount of water circulates on the surface in a short time; part of it has little interaction with organic soils. There is a certain amount of snow that remains until late in summer, with the proportion increasing with altitude, but also depending on topographic details and the general orientation of the catchment. Snow, and to a large extent water from melting snow, has some chemically distinctive features (Catalan, 1988, 1992) including a higher $\mathrm{NH}_{4}^{+}$content than that of water in streams, and null or very low DRSi. However, during snowpack melting, there is differential solute migration; as the thaw progresses, the resultant water contains less and less salts: they all, including $\mathrm{NH}_{4}^{+}$, decrease to very low levels (Brimblecombe et al., 1987; Catalan, 1989).

The correlation between EW and DCMW variables (Fig. 2, Table 3) indicates that features of the spring overturn are not completely erased during stratification. The influence of spring overturn is more important for $\mathrm{NO}_{3}^{-}$than $\mathrm{NH}_{4}^{+}$. This is supported by the similarity between EW and DCMW $\mathrm{NO}_{3}^{-}$concentrations (paired $t=0.6, \mathrm{df}=7, p$ value $=0.6$ ) and isotopic composition values (paired $t=0.6$, $\mathrm{df}=7, p$-value $=0.6)($ Fig. 2$)$ and the correlations between $\mathrm{EW}$ isotopic composition and DCMW concentrations and, vice versa, DCMW isotopic composition and EW concentration (Table 4).

The higher the elevation, the lower the $\mathrm{NO}_{3}^{-}$concentration and the more negative the isotopic values (Table 5, Fig. 3). The slightly skewed relationship (Fig. 3) and the specific isotopic values at the extremes suggest that the pattern may result from the mixing of two $\mathrm{NO}_{3}^{-}$sources, namely: one related to the snowpack with only a superficial flow path; and the other closely related to organic soils. As mentioned above, snowpack melting implies a differential elution of anions, thus later meltwater is poorer in $\mathrm{NO}_{3}^{-}$than it is initially (Tsiouris et al., 1985; Berg, 1992). As the thaw advances, the snow influence is characterised by waters containing very little salts. The isotopic composition of $\mathrm{NO}_{3}^{-}$in this superficial flow path can easily be affected by nitrification, which results in a decline of the already low $\delta^{15} \mathrm{~N}_{-} \mathrm{NO}_{3}^{-}$values from precipitation. The effects of nitrification on the isotopic composition of $\mathrm{NO}_{3}^{-}$in water circulating through soils may be less apparent for several reasons. Firstly, the $\mathrm{NH}_{4}^{+}$substrate for nitrification presents higher values in soils than in snow. Secondly, denitrification in low oxygenated soils can offset nitrification effects in more aerated soils. Thirdly, larger concentrations may be less sensitive to mixing effects. Moreover, the relationships of $\delta^{15} \mathrm{~N}_{-} \mathrm{NO}_{3}^{-}$with DOC and with pore water $\mathrm{NH}_{4}^{+}$and $\mathrm{NO}_{3}^{-}$concentrations indicate that in-lake dynamics also plays a significant role in $\delta^{15} \mathrm{~N}_{-} \mathrm{NO}_{3}^{-}$variation. During lake overturn, exchange with sediments is enhanced and the high $\mathrm{NH}_{4}^{+}$concentrations in the sediments could be a source of nitrification within the lake. As SPW $\delta^{15} \mathrm{~N}_{-} \mathrm{NH}_{4}^{+}$ values are about $2 \%$, nitrification will yield $\delta^{15} \mathrm{~N}^{-\mathrm{NO}_{3}^{-}}$of about $-8 \%$ or lower, as observed in the lakes with the highest $\mathrm{NH}_{4}^{+}$concentrations in their sediment (Fig. 3). The relationship between $\mathrm{DCMW} \mathrm{NO}_{3}^{-}$and $\delta^{15} \mathrm{~N}^{-\mathrm{NO}_{3}^{-}}$may simply reflect the relationship between $\mathrm{NO}_{3}^{-}$concentration in DCMW and SPW.

The correlation between scree proportion in the catchment and DCMW $\delta^{15} \mathrm{~N}-\mathrm{NH}_{4}^{+}$indicates that conditions during spring lake overturn also influence $\mathrm{NH}_{4}^{+}$isotopic composition. In this case, there is no relationship between concentration and the isotopic composition, so there must be a complex situation of mixing or fractionation processes. Higher scree proportion corresponds to lower $\delta^{15} \mathrm{~N}_{-} \mathrm{NH}_{4}^{+}$ values (Fig. 3). This may indicate that during thawing in these catchments there is less water circulating through organic soils, in which the process of organic matter decay enriches the $\delta^{15} \mathrm{~N}$ of the soil DIN. More negative $\delta^{15} \mathrm{~N}^{-\mathrm{NH}_{4}^{+}}$ values in deeper lakes (i.e., photic index $<100 \%$ ) may indicate less influence of $\mathrm{NH}_{4}^{+}$diffusing from sediments and a lower up-take by phytoplankton and periphyton than in lakes where the bottom is well illuminated (Fig. 3). The low $\mathrm{NH}_{4}^{+}$ concentrations, which are related to the fact that algae prefer this $\mathrm{N}$ source over $\mathrm{NO}_{3}^{-}$whilst $\mathrm{NH}_{4}^{+}$concentration is above approximately $1 \mu \mathrm{mol} \mathrm{L}{ }^{-1}$, probably facilitate some differentiation between epilimnetic and hypolimnetic isotopic signatures and part of the high variation in $\delta^{15} \mathrm{~N}^{-\mathrm{NH}_{4}^{+}}$observed between lakes (Table 3 ).

In the epilimnion, there were significant correlations between DRSi, $\mathrm{NH}_{4}^{+}$concentration and isotopic composition. The higher the DRSi, the higher the $\delta^{15} \mathrm{~N}^{-\mathrm{NH}_{4}^{+}}$levels. This suggested a simple case of mixing of two water sources with contrasting DRSi and $\delta^{15} \mathrm{~N}_{-} \mathrm{NH}_{4}^{+}$characteristics (Fry, 2002). However, the linear correlation between DRSi and $\mathrm{NH}_{4}^{+}$concentration $\left(\mathrm{EWNH}_{4}^{+}=0.17+0.025 \mathrm{DRSi}, r^{2}=0.74, p<0.006\right)$ indicated that the two sources differ in $\mathrm{NH}_{4}^{+}$and thus, we cannot infer the $\delta^{15} \mathrm{~N}^{-\mathrm{NH}_{4}^{+}}$of the sources directly from the DRSi relationship. However, there was a linear relationship between $\delta^{15} \mathrm{~N}^{-\mathrm{NH}_{4}^{+}}$and the inverse of the concentration (Fig. 3), $\delta^{15} \mathrm{~N}^{-N_{4}^{+}}=6.23-6.07\left(1 / \mathrm{EWNH}_{4}^{+}\right), r^{2}=0.63$; $p<0.019$, which indicates a possible mixing of two sources with different but constant concentrations and isotopic compositions (Keeling, 1958; Fry, 2006). Although from these two relationships it is not possible to calculate the exact values of concentration and $\delta^{15} \mathrm{~N}$ in the sources, it is possible to identify some important features of these sources and the mixing proportions, based on the following assumptions: 
(i) the variables involved are related according to the parameters estimated above in the two equations; (ii) DRSi in one of the sources is close to zero; and (iii) the values of the sources should be higher or lower, respectively, than the maximum and the minimum values measured for each of the variables considered. In Fig. 4 we illustrate one of the multiple solutions satisfying these assumptions. Although other specific values for the two sources are possible, we show a case with one of the lowest DRSi values that conforms with all the assumptions. All the potential solutions share some general features, namely: (i) one of the sources has very low DRSi (close to 0$)$ and $\mathrm{NH}_{4}^{+}\left(<0.5 \mu \mathrm{mol} \mathrm{L}^{-1}\right)$ concentrations, and relatively low negative $\delta^{15} \mathrm{~N}^{-\mathrm{NH}_{4}^{+}}$(approximately $-30 \%$ ); (ii) the other source has much higher concentrations of DRSi $\left(>100 \mu \mathrm{mol} \mathrm{L}^{-1}\right)$ and $\mathrm{NH}_{4}^{+}\left(>3 \mu \mathrm{mol} \mathrm{L}{ }^{-1}\right)$ and positive $\delta^{15} \mathrm{~N}^{-\mathrm{NH}_{4}^{+}}(>4 \%$ ); and (iii) according to the model, in our field samples, the contribution of the source with low DRSi should be higher $(60 \%-90 \%)$ than the source with higher values. Low silicate and low $\mathrm{NH}_{4}^{+}$features relate the source to the snow water from late snowpack thawing. According to the $\delta^{15} \mathrm{~N}^{-\mathrm{NH}_{4}^{+}}$measured in precipitation, negative values could be expected, but probably not so low. In future studies it would be interesting to examine whether during snowpack melting there is ${ }^{15} \mathrm{~N}$ depletion of the remaining $\mathrm{NH}_{4}^{+}$. High silicate and high $\delta^{15} \mathrm{~N}_{-} \mathrm{NH}_{4}^{+}$relate the second source to the soil solution, which under similar climate conditions shows values higher than 4\%o (Amundson et al., 2003; Makarov, 2009). Similarly to the case of DCMW, it seems that these two different pathways to the streams, and eventually the lake, determine most of the EW variation in $\delta^{15} \mathrm{~N}-\mathrm{NH}_{4}^{+}$. However, there is a difference with respect to DCMW; in the EW case there is no correlation between altitude, or any feature changing progressively with altitude such as land cover types, and $\delta^{15} \mathrm{~N}_{-} \mathrm{NH}_{4}^{+}$. Why should the connection between the snow influence and general catchment features be lost in EW as summer progresses? We hypothesise that it is due to the increasingly local character that the influence of temporary snow patches and snowfields has as thawing and summer progress. When snow is still abundant during the early thaw, average characteristics of the catchment, with a marked altitudinal change, are relevant enough to characterise water flowing into the lakes. However, when snow only remains in more sheltered areas, average characteristics fail to capture the contribution of this snow, which is highly influenced by the particular circumstances of each lake. For instance, lakes in direct contact with areas of scree or large boulders may receive more snow-like influence despite not being at higher altitudes.

\subsection{Concluding remarks}

The isotopic composition of DIN differs markedly between that in SPW and in the water column up and down the altitudinal gradient of the lakes considered. Ammonium in pore water has higher $\delta^{15} \mathrm{~N}$ than water column DIN, and shows
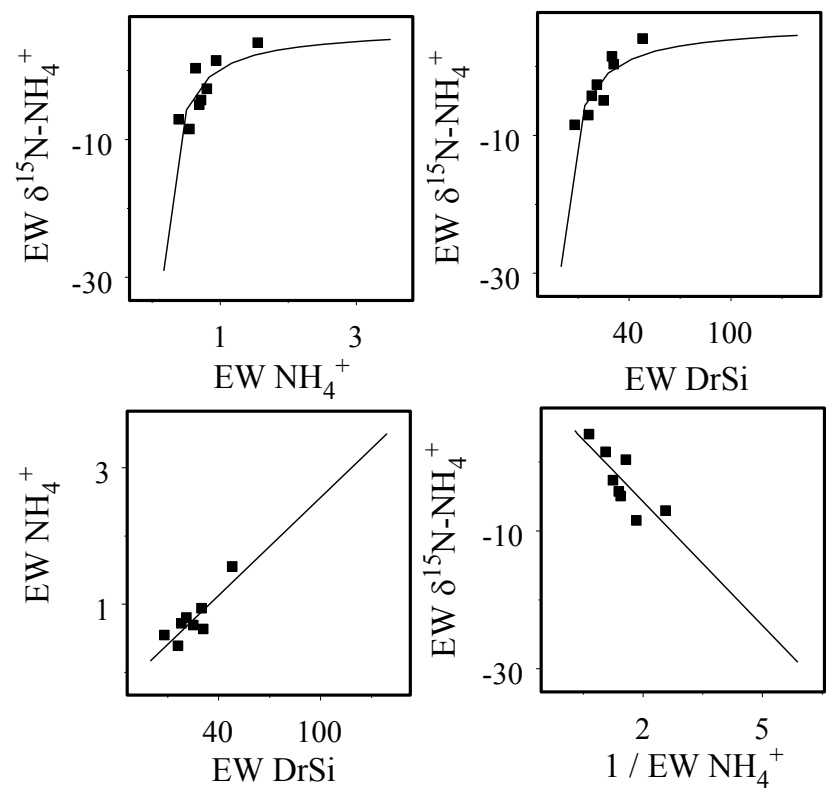

Fig. 4. Comparison between measured field data (symbols) and estimated values (line) based on the mixing of two hypothetical sources with the following characteristics: source $\mathrm{A}, \mathrm{DRSi}=0 \mu \mathrm{molL} \mathrm{L}^{-1}$; $\mathrm{NH}_{4}^{+}=0.17, \delta^{15} \mathrm{~N}_{-} \mathrm{NH}_{4}^{+}=-29.5 \%$; source $\mathrm{B}, \mathrm{DRSi}=120 \mu \mathrm{mol} \mathrm{L}{ }^{-1}$; $\mathrm{NH}_{4}^{+}=3.17, \delta^{15} \mathrm{~N}^{-\mathrm{NH}_{4}^{+}}=4.3 \%$.

relatively little variation between lakes. The difference between pore water and water column $\delta^{15} \mathrm{~N}_{-} \mathrm{NH}_{4}^{+}$is probably related to organic matter diagenesis, which occurs under similar conditions in all these mountain lakes. Factors that are external to the lakes do not appear to be relevant in explaining any isotopic variation in pore water.

Water column isotopic variation seems to be mostly related to catchment water flow paths to the lake. The influence of snow, through rocky surface flow paths, results in a DIN pool depleted in ${ }^{15} \mathrm{~N}$, whereas flow paths including circulation through more heavily vegetated areas provide higher $\delta^{15} \mathrm{~N}$. Similarities between epilimnetic and hypolimnetic DIN indicate that the thawing period has a large influence on establishing the differences between lakes in DIN isotopic composition. SPW DIN also plays a role in $\delta^{15} \mathrm{~N}$ $\mathrm{NO}_{3}^{-}$, related to in-lake dynamics. Concerning epilimnetic $\delta^{15} \mathrm{~N}^{-\mathrm{NH}_{4}^{+}}$, the influence of snow probably acquires a more local character as summer advances, whereas DCMW $\delta^{15} \mathrm{~N}$ $\mathrm{NH}_{4}^{+}$is further influenced by lake photic characteristics in the hypolimnion. The phytoplankton use of $\mathrm{NO}_{3}^{-}$as an alternative $\mathrm{N}$ source when $\mathrm{NH}_{4}^{+}$concentration in the water column is low, and the later regeneration by food web organisms, may result in highly depleted water column $\delta^{15} \mathrm{~N}$ $\mathrm{NH}_{4}^{+}$. Overall, the role of the snowpack in lake water column $\delta^{15} \mathrm{~N}-\mathrm{NH}_{4}^{+}$throughout an annual cycle merits further research (Ohte et al., 2004). 
In summary, we can characterise lake isotopic composition according to the degree of snow-type or soil-type influences. The differentiation bears some relation to altitude, but does not exclusively follow the elevation. Catchment characteristics and the specific location of lakes within the catchment appear more relevant in determining the isotopic composition of ammonium. Under the scenarios proposed here, lakes with a greater snow-type influence may provide a more reliable index of changes in $\mathrm{N}$ deposition and pollution sources, whereas lakes with a greater soil-type influence may reflect long-term effects on vegetation and soil dynamics.

Acknowledgements. This study was supported by the EU project Euro-Limpacs (GOCE-CT-2003-505540) and the Spanish Government via project Graccie (CSD2007-00067). We are grateful for technical advice from E. Martí, D. von Schiller and M. Ribot; and also for field assistance from M. Bacardit, E. O. Casamayor, J. C. Auguet, A. Hervas and J. Arola. We thank two anonymous referees and the associated editor, Steven Bouillon, for valuable comments and suggestions. One of the authors, M. B., thanks the Spanish Ministerio de Educación y Ciencia for a FPU grant.

Edited by: S. Bouillon

\section{References}

Amundson, R., Austin, A. T., Schuur, E. A. G., Yoo, K., Matzek, V., Kendall, C., Uebersax, A., Brenner, D., and Baisden, W. T.: Global patterns of the isotopic composition of soil and plant nitrogen, Global Biogeochem. Cy., 17, 1031-1040, 2003.

Berg, N. H.: Ion elution and release sequence from deep snowpacks in the Central Sierra-Nevada, California, Water Air Soil Poll., 61, 139-168, 1992.

Brimblecombe, P., Clegg, S. L., Davies, T. D., Shooter, D., and Tranter, M.: Observations of the preferential loss of major ions from melting snow and laboratory ice, Water Res., 21, 12791286, 1987.

Buchaca, T. and Catalan, J.: On the contribution of phytoplankton and benthic biofilms to the sediment record of marker pigments in high mountain lakes, J. Paleolimnol., 40, 369-383, 2008.

Camarero, L. and Catalan, J.: Chemistry of bulk precipitation in the central and eastern Pyrenees, northeast Spain, Atmos. Environ., 27, 83-94, 1993.

Camarero, L.: Assay of soluble reactive phosphorus at nanomolar levels in nonsaline waters, Limnol. Oceanogr., 39, 707-711, 1994.

Camarero, L. and Catalan, J.: Variability in the chemistry of precipitation in the Pyrenees (northeastern Spain): Dominance of storm origin and lack of altitude influence, J. Geophys. Res., 101, 29491-29498, 1996.

Campbell, D. H., Baron, J. S., Tonnessen, K. A., Brooks, P. D., and Schuster, P. F.: Controls on nitrogen flux in alpine/subalpine watersheds of Colorado, Water Resour. Res., 36, 37-47, 2000.

Casals-Carrasco, P., Ventura, M., Gond, V., Madhavan, B., Pretus, J., and Catalan, J.: A spectral approach to satellite land cover classification of remote European mountain lake districts, Fund. Appl. Limnol., Adv. Limnol., 62, 353-365, 2009.
Catalan, J.: Physical properties of the environment relevant to the pelagic ecosystem of a deep high-mountain lake (estany Redó, central Pyrenees), Oecol. Aquat., 9, 89-123, 1988.

Catalan, J.: The Winter Cover of A High-Mountain Mediterranean Lake (Estany-Redó, Pyrenees), Water Resour. Res., 25, 519-527, 1989.

Catalan, J.: Evolution of dissolved and particulate matter during the ice-covered period in a deep, high-mountain lake, Can. J. Fish. Aquat. Sci., 49, 945-955, 1992.

Catalan, J., Ventura, M., Brancelj, A., Granados, I., Thies, H., Nickus, U., Korhola, A., Lotter, A. F., Barbieri, A., Stuchlik, E., Lien, L., Bitusík, P., Buchaca, T., Camarero, L., Goudsmit, G. H., Kopacek, J., Lemcke, G., Livingstone, D. M., Müller, B., Rautio, M., Sisko, M., Sorvari, S., Sporka, F., Strunecky, O., and Toro, M.: Seasonal ecosystem variability in remote mountain lakes: implications for detecting climatic signals in sediment records, J. Paleolimnol., 28, 25-46, 2002.

Catalan, J., Barbieri, M. G., Bartumeus, F., Bitusík, P., Botev, I., Brancelj, A., Cogalniceanu, D., Manca, M., Marchetto, A., Ognjanova-Rumenova, N., Pla, S., Rieradevall, M., Sorvari, S., Stefkova, E., Stuchlik, E., and Ventura, M.: Ecological thresholds in European alpine lakes, Freshwater Biol., 54, 2494-2517, 2009a.

Catalan, J., Curtis, C. J., and Kernan, M.: Remote European mountain lake ecosystems: regionalisation and ecological status, Freshwater Biol., 54, 2419-2432, 2009b.

Choi, W. J., Lee, S. M., and Yoo, S. H.: Increase in $\delta^{15} \mathrm{~N}$ of nitrate through kinetic isotope fractionation associated with denitrification in soil, Agric. Chem. Biotechnol., 44, 135-139, 2001.

Croisé, L., Ulrich, E., Duplat, P., and Jaquet, O.: Two independent methods for mapping bulk deposition in France, Atmos. Environ., 39, 3923-3941, 2005.

Delwiche, C. C. and Steyn, P. L.: Nitrogen isotope fractionation in soils and microbial reactions, Environ. Sci. Technol., 4, 929-935, 1970.

Doi, H., Kikuchi, E., Shikano, S., and Takagi, S.: A study of the nitrogen stable isotope dynamics of phytoplankton in a simple natural ecosystem, Aquat. Microb. Ecol., 36, 285-291, 2004.

Freyer, H. D.: Seasonal-variation of N-15-N-14 ratios in atmospheric nitrate species, Tellus, 43, 30-44, 1991.

Fry, B.: Conservative mixing of stable isotopes across estuarine salinity gradients: a conceptual framework for monitoring watershed influences on downstream fisheries production, Estuaries, 25, 264-271, 2002.

Fry, B.: Stable isotope ecology, Springer, 1-308, 2006.

Gonfiantini, R.: Standards for stable isotope measurements in natural compounds, Nature, 271, 534-536, 1978.

Grasshoff, K., Ehrhardt, M., and Kremling, K.: Methods of seawater analysis, 2nd edition, Chemie, Weinheim, 419 pp., 1983.

Gruber, N. and Galloway, J. N.: An Earth-system perspective of the global nitrogen cycle, Nature, 451, 293-296, 2008.

Hastings, M. G., Sigman, D. M., and Lipschultz, F.: Isotopic evidence for source changes of nitrate in rain at Bermuda, J. Geophys. Res., 108, 4790-4801, 2003.

Heiri, O., Lotter, A. F., and Lemcke, G.: Loss on ignition as a method for estimating organic and carbonate content in sediments: reproducibility and comparability of results, J. Paleolimnol., 25, 101-110, 2001. 
Hoch, M. P., Fogel, M. L., and Kirchman, D. L.: Isotope fractionation associated with ammonium uptake by a marine bacterium, Limnol. Oceanogr., 37, 1447-1459, 1992.

Hogberg, P.: N-15 natural abundance in soil-plant systems, New Phytol., 137, 179-203, 1997.

Holmes, R. M., McClelland, J. W., Sigman, D. M., Fry, B., and Peterson, B. J.: Measuring N-15-NH4+ in marine, estuarine and freshwaters: an adaptation of ammonia diffusion method for samples with low ammonium concentrations, Mar. Chem., 60, 235-243, 1998.

Hood, E. W., Williams, M. W., and Caine, N.: Landscape controls on organic and inorganic nitrogen leaching across an alpine/subalpine ecotone, Green Lakes Valley, Colorado Front Range, Ecosystems, 6, 31-45, 2003.

Keeling, C. D.: The concentration and isotopic abundances of atmospheric carbon dioxide in rural areas, Geochim. Cosmochim. Acta, 13, 322-335, 1958.

Kopacek, J., Stuchlik, E., and Wright, R. F.: Long-term trends and spatial variability in nitrate leaching from alpine catchment lake ecosystems in the Tatra Mountains (Slovakia-Poland), Environ. Pollut., 136, 89-101, 2005.

Korner, C.: The use of "altitude" in ecological research, Trends Ecol. Evol., 22, 569-574, 2007.

Lehmann, M. F., Bernasconi, S. M., Barbieri, A., and McKenzie, J. A.: Preservation of organic matter and alteration of its carbon and nitrogen isotope composition during simulated and in situ early sedimentary diagenesis, Geochim. Cosmochim. Acta, 66, 3573-3584, 2002.

Makarov, M.: The nitrogen isotopic composition in soils and plants: Its use in environmental studies (A Review), Eurasian Soil Sci., 42, 1335-1347, 2009.

Mariotti, A., Germon, J. C., Hubert, P., Kaiser, P., Letolle, R., Tardieux, A., and Tardieux, P.: Experimental-determination of nitrogen kinetic isotope fractionation - Some principles - Illustration for the denitrification and nitrification processes, Plant Soil, 62, 413-430, 1981.

Moore, H.: The isotopic composition of ammonia, nitrogen dioxide and nitrate in the atmosphere, Atmos. Environ., 11, 1239-1243, 1977.

Mosello, M., Lami, A., Marchetto, A., Rogora, M., Wathne, B., Lien, L., Catalan, J., Camarero, L., Ventura, M., Psenner, R., Koinig, K., Thies, H., Sommaruga-Wograth, S., Nickus, U., Tait, D., Thaler, B., Barbieri, A., and Harriman, R.: Trends in the chemical composition of high altitude lakes selected for the MOLAR project, Water Air Soil Poll., 2, 75-89, 2002.
Ohte, N., Sebestyen, S. D., Shanley, J. B., Doctor, D. H., Kendall, C., Wankel, S. D., and Boyer, E. W.: Tracing sources of nitrate in snowmelt runoff using a high-resolution isotopic technique, Geophys. Res. Lett., 31, L21506, doi:10.1029/2004g1020908, 2004.

Owens, N. J. P.: Natural Variations in N-15 in the MarineEnvironment, Adv. Mar. Biol., 24, 389-451, 1987.

Rogora, M., Marchetto, A., and Mosello, R.: Trends in the chemistry of atmospheric deposition and surface waters in the Lake Maggiore catchment, Hydrol. Earth Syst. Sci., 5, 379-390, doi:10.5194/hess-5-379-2001, 2001.

Shearer, G. and Kohl, D. H.: N2-Fixation in field settings - estimations based on natural N-15 abundance, Aust. J. Plant Physiol., 13, 699-756, 1986.

Sigman, D. M., Altabet, M. A., Michener, R., McCorkle, D. C., Fry, B., and Holmes, R. M.: Natural abundance-level measurement of the nitrogen isotopic composition of oceanic nitrate: an adaptation of the ammonia diffusion method, Mar. Chem., 57, 227-242, 1997.

Solórzano, L.: Determination of ammonia in natural waters by phenolhypochlorite method, Limnol. Oceanogr., 14, 799-801, 1969.

Spoelstra, J., Schiff, S. L., Jeffries, D. S., and Semkin, R. G.: Effect of storage on the isotopic composition of nitrate in bulk precipitation, Environ. Sci. Technol., 38, 4723-4727, 2004.

Tsiouris, S., Vincent, C. E., and Davies, T. D.: The elution of ions through field and laboratory snowpacks, Ann. Glaciol., 7, 196201, 1985.

Venables, W. and Ripley, B. D.: Modern applied statistics with SPlus, Springer, New York, 462 pp., 1994.

Wada, E. and Hattori, A.: Nitrogen isotope effects in the assimilation of inorganic nitrogenous compounds by marine diatoms, Geomicrobiol. J., 1, 85-101, 1978.

Wookey, P. A., Aerts, R., Bardgett, R. D., Baptist, F., Brathen, K. A., Cornelissen, J. H. C., Gough, L., Hartley, I. P., Hopkins, D. W., Lavorel, S., and Shaver, G. R.: Ecosystem feedbacks and cascade processes: understanding their role in the responses of Arctic and alpine ecosystems to environmental change, Global Change Biol., 15, 1153-1172, 2009.

York, J. K., Tomasky, G., Valiela, I., and Repeta, D. J.: Stable isotopic detection of ammonium and nitrate assimilation by phytoplankton in the Waquoit Bay estuarine system, Limnol. Oceanogr., 52, 144-155, 2007. 